Article

\title{
Improving the Quality and Safety of Fresh Camel Meat Contaminated with Campylobacter jejuni Using Citrox, Chitosan, and Vacuum Packaging to Extend Shelf Life
}

\author{
Hany M. Yehia ${ }^{1,2, *}$, , Abdulrahman H. Al-Masoud ${ }^{1}$, Manal F. Elkhadragy ${ }^{3}$, Shereen M. Korany ${ }^{3,4}$, \\ Hend M. S. Nada ${ }^{5}$, Najla A. Albaridi ${ }^{6}{ }^{(0)}$, Abdulhakeem A. Alzahrani ${ }^{1}$ and Mosffer M. AL-Dagal ${ }^{1}$
}

1 Department of Food Science and Nutrition, College of Food and Agriculture Sciences, King Saud University, Riyadh 11451, Saudi Arabia; amasood@ksu.edu.sa (A.H.A.-M.); aabdulhakeem@ksu.edu.sa (A.A.A.); maldagal@ksu.edu.sa (M.M.A.-D.)

2 Department of Food Science and Nutrition, Faculty of Home Economics, Helwan University, Cairo 11221, Egypt

3 Department of Biology, Faculty of Science, Princess Nourah Bint Abdulrahman University, Riyadh 11671, Saudi Arabia; mfelkhadragy@pnu.edu.sa (M.F.E.); shirienmagdy@yahoo.com (S.M.K.)

4 Department of Botany and Microbiology, Faculty of Science, Helwan University, Cairo 11421, Egypt

5 Department of Microbiology, Faculty of Veterinary Medicine, Zagazig University, Zagazig 44519, Egypt; Hend.saeed@hotmail.com

check for updates

Citation: Yehia, H.M.; Al-Masoud, A.H.; Elkhadragy, M.F.; Korany, S.M.; Nada, H.M.S.; Albaridi, N.A.; Alzahrani, A.A.; AL-Dagal, M.M. Improving the Quality and Safety of Fresh Camel Meat Contaminated with Campylobacter jejuni Using Citrox, Chitosan, and Vacuum Packaging to Extend Shelf Life. Animals 2021, 11, 1152. https:// doi.org/10.3390/ani11041152

Academic Editors: Mandy Paterson and Beniamino T. Cenci-Goga

Received: 23 February 2021

Accepted: 15 April 2021

Published: 17 April 2021

Publisher's Note: MDPI stays neutral with regard to jurisdictional claims in published maps and institutional affiliations.

Copyright: (c) 2021 by the authors. Licensee MDPI, Basel, Switzerland. This article is an open access article distributed under the terms and conditions of the Creative Commons Attribution (CC BY) license (https:/ / creativecommons.org/licenses/by/ $4.0 /)$.
6 Nutrition and Food Science, Department of Physical Sport Science, Princess Nourah bint Abdulrahman University, Riyadh 11671, Saudi Arabia; naalbaridi@pnu.edu.sa

* Correspondence: hanyehia@ksu.edu.sa

Simple Summary: This study aimed to investigate the influence of using $1 \%$ or $2 \%$ Citrox alone or in combination with $1 \%$ chitosan on the survival of Campylobacter jejuni in camel meat slices vacuum-packed and stored at 4 or $10{ }^{\circ} \mathrm{C}$ for 30 days. The shelf life of camel meat was 30 days longer using $1 \%$ or $2 \%$ Citrox in combination with $1 \%$ chitosan than when using Citrox alone. The reductions ranged from 4.0 to 3.5 logarithmic cycles during the storage period at both 4 and $10{ }^{\circ} \mathrm{C}$. The quality of camel meat treated with Citrox plus chitosan was also better than that of the control meat and of meat treated with $0.85 \% \mathrm{NaCl}$.

Abstract: Camel meat is one of the most consumed meats in Arab countries. The use of natural antimicrobial agents to extend the shelf life of fresh camel meat, control Campylobacter jejuni contamination, and preserve meat quality is preferred. In this study, we determined the antimicrobial effects of using $1 \%$ or $2 \%$ Citrox alone or in combination with $1 \%$ chitosan on the survival of $C$. jejuni in vitro and on camel meat samples during storage at 4 or $10{ }^{\circ} \mathrm{C}$ for 30 days in vacuum packaging. We determined the total viable count (TVC ( $\mathrm{cfu} / \mathrm{g})$ ), total volatile base nitrogen (TVB-N) content, and $\mathrm{pH}$ of the treated camel meat samples every three days during storage. The shelf lives of camel meat samples treated with $2 \%$ Citrox alone or in combination with $1 \%$ chitosan were longer than those of camel meat samples treated with $1 \%$ Citrox alone or in combination with $1 \%$ chitosan at both the 4 and $10{ }^{\circ} \mathrm{C}$ storage temperatures, with TVCs of $<100 \mathrm{cfu} / \mathrm{g}$ after the first ten days and six days of storage at 4 and $10{ }^{\circ} \mathrm{C}$, respectively. The addition of Citrox ( $1 \%$ and $\left.2 \%\right)$ and $1 \%$ chitosan to camel meat samples and the application of vacuum storage were more effective than using Citrox $(1 \%$ and $2 \%)$ alone and led to a reduction in C. jejuni in approximately 4.0 and $3.5 \log$ cycles at 4 and $10{ }^{\circ} \mathrm{C}$, respectively. The experimental results demonstrated that using a Citrox-chitosan combination improved the quality of camel meat and enhanced the long-term preservation of fresh meat for up to or more than 30 days at $4^{\circ} \mathrm{C}$.

Keywords: camel meat; C. jejuni; citrox; chitosan; total volatile base nitrogen (TVB-N); sensory evaluation 


\section{Introduction}

One of the most common causes of bacterial gastroenteritis consists of Campylobacter species, which are distributed globally. The worldwide rate of Campylobacter infection has increased in the last decade [1,2], and such infections have been confirmed to pose severe public health risks [3]. Campylobacter infection is a zoonosis that causes foodborne illness [4]. The consumption of undercooked red meat or poultry [5] is considered a risk factor [6] for Campylobacter infection. Foods containing meat or animal products can be contaminated with Campylobacter during slaughter and carcass dressing [7-9]. Meat and meat products, such as burgers and sausages, contain high protein levels and are regular components of human diets. Therefore, their hygiene is essential to public health, as the consumption of poor-quality meats can cause infections [10]. Foodborne bacteria, such as Campylobacter species, are typical foodborne pathogens and are responsible for outbreaks $[11,12]$.

Camel meat contains high-quality protein and has low fat and cholesterol contents and higher polyunsaturated fatty acid contents than meat from other animals [13]. In the last decade, camel meat has received increasing attention because it has caused unrecognized foodborne diseases in developing countries [14]. Zoonotic microbes, such as Enterococcus sp., Staphylococcus aureus, and Campylobacter spp., and many other foodborne pathogens contaminate meat. The gastrointestinal tract of food-producing animals can harbor many of these pathogens, which can contaminate meat during processing at an abattoir, resulting in subsequent human illnesses [15]. The Kingdom of Saudi Arabia is projected to be the largest consumer of camel meat in the Arabian Gulf region, and the demand for camel meat is expected to grow as the population, number of visitors, and consumer preference for fresh camel meat increase.

The use of chemical additives in foods has risen, while the safety of these chemicals has been improved. However, worldwide consumer demand for the use of natural products to preserve foods has increased. Recently, companies have been manufacturing Citrox to meet this demand. Due to its plant origins, including citrus extract, citric acid, and polyphenols, it complies with the requirements of European Regulation 2092/91 and EC Directive 89/107/EEC. Citrox interacts with organic matter and impacts microorganisms in various ways, including the deterioration of bacterial films, the breaking down of biofilms, and the reducing of foodborne pathogens, which extend the shelf life of meat. Citrox can be applied directly to food as an additive and conforms to BS EN 1276 (European suspension test).

Citrox includes a range of bioflavonoids derived from citrus fruits. Bioflavonoid and organic acid compounds are effective against viruses, bacteria, molds, and yeasts and exhibit synergistic activity. Citrox can be described as follows: It is composed of natural organic acids and has broad-spectrum activity against microorganisms (Gram-negative and Gram-positive bacteria), molds, yeasts, and viruses. It is safe and exerts its effects while being volatile, nonmutagenic, nontoxic, noncorrosive, nontainting, and noncarcinogenic. It has the ability to break down bacterial biofilms, appears active in the presence of organic matter and debris, and can destroy cell walls.

Chitosan is an aminopolysaccharide that contains a positive electrical charge and bonds to negatively charged molecules. Chitosan and its derivatives are of interest because they are nontoxic antimicrobial and biodegradable biopolymers with many functions [16-18]. Chitosan is soluble in various acids, such as hydrochloric, nitric, acetic, phosphoric, and perchloric acids [19-21].

The solubility of chitosan in aqueous acidic solutions with a $\mathrm{pH}$ lower than 6.5 can be altered and depends on the depolymerization and chemical modification of the primary and secondary hydroxyl groups [22]. Chitosan has antimicrobial activities against Grampositive and Gram-negative bacteria [23], so it is considered a promising agent for extending the shelf life of food, preserving fresh food, and maintaining food safety.

Chitosan can be used alone or in combination with organic matter to increase its beneficial effects. Roller et al. (2002) [24] combined chitosan with glutamate, sulfite, and carnocin and added the compounds to pork sausages for preservation. 
The biomarker which is used as a protein and amine degrader in meat is considered to be total volatile basic nitrogen (TVB-N). Therefore, measurements of total volatile bases nitrogen (TVB-N) can help in the diagnosis of meat contamination. TVB-N values are raised in meat during storage and aligned with other biomarkers of spoilage (i.e., duration time of storage, temperature and packaging conditions, etc.). Also, the $\mathrm{pH}$ of meat is considered as the main factor in the determination of fresh meat since it can measure the rate of oxidation of myoglobin and lipids, and therefore of the meat itself.

Sensory analysis is also regarded as a useful tool for the qualitative evaluation of foods; an increase in the level of chemical compounds, total viable count (TVC), or physical alteration of the food matrix results in changes in sensory attributes.

To our knowledge, no studies have been conducted using Citrox alone or in combination with chitosan for the treatment of camel meat to evaluate the effects of Citrox on the survival of C. jejuni and the ability to extend the shelf life and quality of camel meat. Thus, we used $1 \%$ and $2 \%$ Citrox alone or combined with $1 \%$ chitosan to treat vacuum-packed camel meat slices stored at 4 or $10{ }^{\circ} \mathrm{C}$ for 30 days, and we determined the total viable count (TVC) of C. jejuni and the total basic nitrogen (TVB-N) and physicochemical and sensory parameters of the meat.

\section{Materials and Methods}

\subsection{Camel Meat Samples}

Camel meat samples were obtained from markets distributed in Riyadh, Saudi Arabia. The samples were transported to the laboratory of Food Microbiology, College of Food and Agriculture Sciences, King Saud University, under cooled conditions and incubated in a refrigerator at $2{ }^{\circ} \mathrm{C}$ for the experiments.

\subsection{Campylobacter jejuni}

An inoculum of C. jejuni ATCC 33291 ( $10^{4}$ colony-forming units (cfu/mL)) was used. Two types of media were used to activate the strain, Campylobacter blood-free selective medium (modified CCDA-Preston) (Oxoid CM 0739, Basingstoke, UK) supplemented with CCDA Selective Supplement (SR 0155) and Bolton Selective Enrichment Broth (Oxoid CM0983, Basingstoke, UK), and then cooled to 45 to $50{ }^{\circ} \mathrm{C}$, and $25 \mathrm{~mL}$ of laked horse blood (SR0048) and one vial of Bolton Broth Selective Supplement (Oxoid SR0183 Basingstoke, UK), were aseptically added. The plates were incubated at $42{ }^{\circ} \mathrm{C}$ for 24 to $72 \mathrm{~h}$.

\subsection{Preparation of Citrox}

Pure Citrox was prepared by mixing organic acids in $100 \mathrm{~mL}$ of distilled water with a citric acid:malic acid:ascorbic acid ratio of 18:18:5 (by weight). The mixture was yellow in color and had a pH of 2.7. Distilled water was used to dilute the Citrox to 1 and $2 \%$ solutions, which were then added to a $1 \%$ chitosan solution before sterilization at $121{ }^{\circ} \mathrm{C}$ for 15 to $20 \mathrm{~min}$. A saline solution of $0.85 \% \mathrm{NaCl}$ was also prepared in large quantities and sterilized along with the other solutions.

\subsection{Camel Meat Samples, Inoculation, Treatment, and Packaging}

Seven hundred and ninety-two camel meat samples weighing approximately $25 \mathrm{~g}$ each were collected. These samples were separated into six groups, A, B, C, D, E, and F, which each contained 198 samples, to determine the TVC, pH, TVB-N, color, and sensory profile.

\section{Treatment Groups}

In Group A, camel meat samples were immersed in an aluminum tray containing $1 \mathrm{~L}$ of $0.85 \% \mathrm{NaCl}$ and left for $2 \mathrm{~min}$. Group A was the negative control.

Group B consisted of camel meat-salt-C. jejuni. The samples were immersed in $1 \mathrm{~L}$ of $0.85 \% \mathrm{NaCl}$, left to drain on a sterilized sieve, placed in a C. jejuni inoculum $\left(\sim 10^{4} \log \mathrm{cfu} / \mathrm{mL}\right)$, and left for $2 \mathrm{~min}$. Group B was the positive control. 
In Groups C and D, camel meat samples were soaked for 2 min in saline solution, placed into a C. jejuni inoculum, and then into either $1 \%$ or $2 \%$ Citrox, and left for a duration suitable to drain the solutions.

Group E consisted of camel meat-salt-C. jejuni-1\% Citrox and 1\% chitosan, as described above.

Group F consisted of camel meat-salt-C. jejuni-2\% Citrox and 1\% chitosan, as mentioned above.

All the samples were packed in transparent polyethylene containers $(16 \times 22 \mathrm{~cm})$, vacuum-sealed (PlusVac 20, KOMET Plochingen, Germany), and stored under cooled conditions in incubators at 4 or $10^{\circ} \mathrm{C}$ for 30 days. Samples were analyzed every three days for the determination of the TVC, $\mathrm{pH}, \mathrm{TVB}-\mathrm{N}$, and sensory profile.

\subsection{In Vitro Activity of Citrox and Chitosan Towards C. jejuni}

This study evaluated the effects of using $1 \%$ or $2 \%$ Citrox alone or in combination with $1 \%$ chitosan on C. jejuni in Campylobacter blood-free selective medium (modified CCDA-Preston) (Oxoid CM 0739, Basingstoke, UK) supplemented with CCDA Selective Supplement (Oxoid SR 0155, Basingstoke, UK) at $42{ }^{\circ} \mathrm{C}$ for 24 to $48 \mathrm{~h}$.

One hundred microliters of C. jejuni ATCC 33291 culture $\left(10^{6} \mathrm{cfu} / \mathrm{mL}\right)$ was spread using a cotton swab on the surface of Campylobacter blood-free selective medium (modified CCDA-Preston) (Oxoid CM 0739, Basingstoke, UK) supplemented with CCDA Selective Supplement (Oxoid SR 0155, Basingstoke, UK). Using the agar diffusion method, a hole with a diameter of $8 \mathrm{~mm}$ was punched aseptically using a sterile cork borer, and $100 \mu \mathrm{L}$ of $1 \%$ or $2 \%$ Citrox solution was introduced into each well. To compare its effects on C. jejuni, $1 \%$ chitosan was mixed with the same volume of $1 \%$ or $2 \%$ Citrox. The plates were then incubated at $42{ }^{\circ} \mathrm{C}$ for 48 to $72 \mathrm{~h}$ under a microaerophilic atmosphere in the presence of $\mathrm{CO}_{2}$. The diameter $(\mathrm{mm})$ of the zone of inhibition was determined.

\subsection{Microbiological Analysis}

Ten grams of a camel meat sample was transferred to $90 \mathrm{~mL}$ of saline solution $(0.85 \%$ $\mathrm{NaCl}$ ), placed in a stomacher bag (Seward Ltd., London, UK), and homogenized for 2 min at room temperature. C. jejuni cells were counted by using the pour-plate method with serial dilution $\left(1 / 10-1 / 10^{3}\right)$. One milliliter of each sample was mixed with Campylobacter blood-free selective medium agar (modified CCDA-Preston, Oxoid CM0739, Basingstoke, UK) supplemented with CCDA Selective Supplement (SR0155, Oxoid CM375, Basingstoke, UK) and incubated at $42{ }^{\circ} \mathrm{C}$ for 48 to $72 \mathrm{~h}$ under a microaerophilic atmosphere in the presence of $\mathrm{CO}_{2}$.

\subsection{Chemical Analysis}

\subsubsection{Total Volatile Base Nitrogen (TVB-N)}

TVB-N was determined according to the method from the AOAC (1990) [25]. Five grams of a camel meat sample was added to $300 \mathrm{~mL}$ of distilled water in a heating flask, and then $2 \mathrm{~g}$ of magnesium oxide and some granules of antifoaming pellets were added. The receiving flasks contained $25 \mathrm{~mL}$ of boric acid (2\%) and a few drops of Tashiro's indicator (consisting of $1.25 \mathrm{~g}$ methyl red and $0.32 \mathrm{~g}$ methylene blue dissolved in $1 \mathrm{~L}$ of $90 \%$ ethanol). The flasks used for the heating and receiving were connected to an evaporator, and the water bath temperature was controlled. After $25 \mathrm{~min}$, distillation was stopped. By using sulfuric acid $(0.05 \mathrm{~N})$, the contents of the receiving flask were titrated to the endpoint, and the TVB-N was determined as follows:

$$
\mathrm{TVB}-\mathrm{N}=(\mathrm{V} \times \mathrm{N} \times 100 \times 14) / \mathrm{W}
$$

where $\mathrm{V}$ is the volume of sulfuric acid $(\mathrm{mL}), \mathrm{N}$ is the normality of sulfuric acid $(0.05 \mathrm{~N})$, and $\mathrm{W}$ is the weight of the sample in grams. 


\subsection{2. $\mathrm{pH}$}

Twenty-five camel meat samples were homogenized in $10 \mathrm{~mL}$ of distilled water, and the $\mathrm{pH}$ was determined by using a pH meter (pH ORION, model 330, Court Vernon Hills, USA), with measurements performed in triplicate.

\subsubsection{Color}

The CIE L*a* ${ }^{*}$ color scales were used to measure the color of camel meat samples and were dependent on the opponent color theory, which assumes that human eye receptors perceive color as pairs of opposites. Color was evaluated using a colorimeter (CR-300 spectrophotometer, Konica Minolta Inc., Tokyo, Japan) and calibrated using black and white reference tiles. $\mathrm{L}^{*}, \mathrm{a}^{*}$, and $\mathrm{b}^{*}$ values were recorded at three different locations on each camel meat sample, and each sample was analyzed in triplicate.

\subsubsection{Sensory Panel Evaluations}

Small cubic camel meat samples were cooked in a microwave oven (Sanyo, Model EM-G1299V, Jiangsu, China) at 1000 watts (temperature of $-90^{\circ} \mathrm{C}$ ) for $10 \mathrm{~min}$. Panels of 10 experienced food scientists were selected to evaluate the sensory attributes of the cooked camel meat. Scales ranging from 0 to 9 were used to estimate the odor and taste acceptability of camel meat samples. The panelists evaluated the products as acceptable or unacceptable in their taste, flavor, and odor. A nine-point hedonic scale was used: $9=$ extremely like, $5=$ moderately like, and $1=$ extremely dislike.

\subsection{Statistical Analysis}

Data are reported as the mean \pm standard deviation $(M \pm S D)$. Analysis of variances was used to determine the difference between the groups and storage periods in a completely randomized factorial design [26]. When a significant main effect was detected, the means were separated using Duncan's multiple range test. Differences between groups with $p<0.05$ were considered significant.

\section{Results and Discussion}

\subsection{Activity of Citrox and Chitosan toward C. jejuni}

The administration of $100 \mu \mathrm{L}$ of a $1 \%$ or $2 \%$ Citrox solution evidently inhibited the growth of $C$. jejuni. However, the zone of inhibition was larger for $2 \%$ Citrox than for $1 \%$ Citrox. However, when using $1 \%$ chitosan mixed with $1 \%$ or $2 \%$ Citrox, there was a more effective and larger zone of inhibition against $C$. jejuni than when using Citrox alone (Figure 1). Therefore, we applied treatments of $1 \%$ or $2 \%$ Citrox with or without $1 \%$ chitosan to camel meat samples and compared the abilities of the treatments using $1 \%$ or $2 \%$ Citrox alone to stop or control the growth of $C$. jejuni in meat samples during storage.

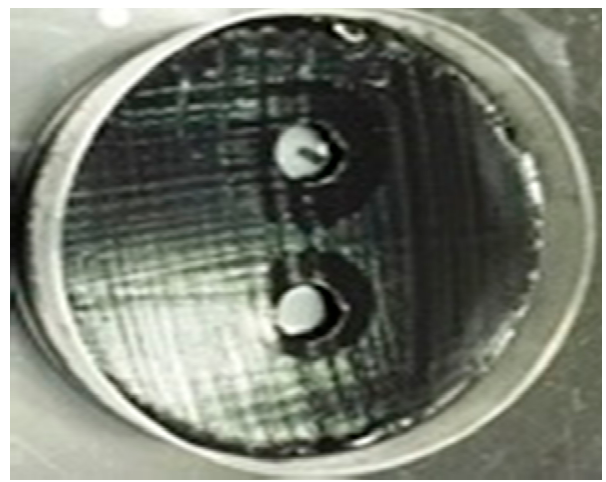

Citrox (1 and $2 \%)$

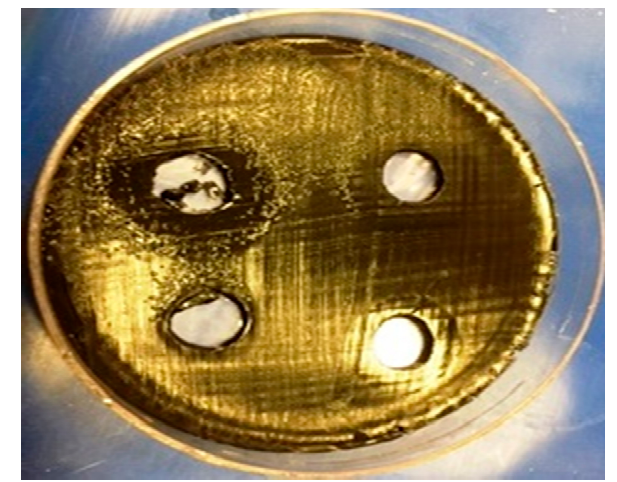

Citrox (1 and $2 \%)$ and chitosan (1\%)

Figure 1. Effect of citrox solution at a concentrations of $1 \%$ and $2 \%$ citrox and $1 \%$ chitosan on Campylobacter jejuni. 


\subsection{Total Viable Count}

The TVC is a microbiological parameter used to determine the counts of $C$. jejuni in camel meat samples. Figure 2 shows the total viable count (TVC) of $C$. jejuni isolated from camel meat sample by pour plate method and using serial dilution of $10-10^{3} / \mathrm{g}$. The colonies appeared as greyish to white on Campylobacter blood-free selective medium (modified CCDA-Preston) after incubation at $42{ }^{\circ} \mathrm{C}$ and under a microaerophilic atmosphere in the presence of $\mathrm{CO}_{2}$.

$1 / 10$

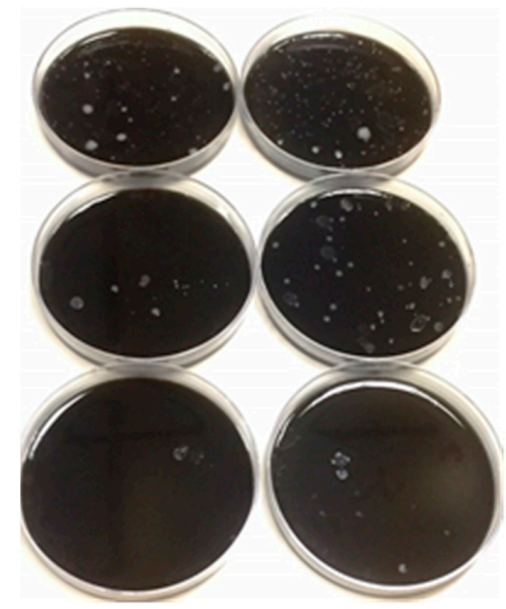

Figure 2. Total viable counts (TVCs) of Campylobacter jejuni ATCC 33291 isolated from camel meat after treatment and cultured on Campylobacter blood-free selective medium (modified CCDA-Preston).

The TVCs of $C$. jejuni in camel meat during 30 days of storage at $10{ }^{\circ} \mathrm{C}$ are presented in Figure 3. The camel meat samples treated with C. jejuni solution (Group B, positive control) exhibited the highest TVC of $\sim 4.5 \mathrm{log} \mathrm{cfu} / \mathrm{g}$ after 12 days of storage (Figure 3). Then, the TVC gradually decreased with continuous growth until it reached $1.5 \mathrm{log} \mathrm{cfu} / \mathrm{g}$ at the end of the storage period of 30 days (Figure 3). However, the TVC in the camel meat samples treated with $0.85 \% \mathrm{NaCl}$ (Group A, negative control) decreased gradually from $3.5 \mathrm{log} \mathrm{cfu} / \mathrm{g}$ at the beginning of the storage period to $<100 \mathrm{cfu} / \mathrm{g}$ by the 18 th day of storage (Figure 3). Group C ( $1 \%$ Citrox) camel meat samples stored at $4{ }^{\circ} \mathrm{C}$ displayed a gradual decrease in TVC from $3.5 \mathrm{log} \mathrm{cfu} / \mathrm{g}$ to $<100 \mathrm{cfu} / \mathrm{g}$ by the 17th day of storage, while the TVC in Group D ( $2 \%$ Citrox) quickly decreased to $<100 \mathrm{cfu} / \mathrm{g}$ after the 9 th day of storage (Figure 3).

The best treatment for decreasing the TVC of $C$. jejuni was the treatment applied to Group F, in which the TVC decreased rapidly from $\log 3.5 \mathrm{cfu} / \mathrm{g}$ to $<100 \mathrm{cfu} / \mathrm{g}$ by the 6th day of storage. Additionally, for Group F, the TVC of C. jejuni decreased by the 10th day of storage at $10^{\circ} \mathrm{C}$ (Figure 3).

The TVCs of $C$. jejuni in camel meat during 30 days of storage at $4{ }^{\circ} \mathrm{C}$ are presented in Figure 4. The camel meat samples treated with the C. jejuni inoculum (Group B, positive control) recorded the highest TVC of $3.8 \mathrm{log} \mathrm{cfu} / \mathrm{g}$; then, the TVC gradually reduced with continuous growth until it reached $2.0 \mathrm{log} \mathrm{cfu} / \mathrm{g}$ after 30 days of storage (Figure 4). However, in the camel meat samples treated with $0.85 \% \mathrm{NaCl}$ (Group A, negative control), the TVC decreased gradually from $3.5 \log \mathrm{cfu} / \mathrm{g}$ to $<100 \mathrm{cfu} / \mathrm{g}$ on the 18th day of storage. The Group C (treated with Citrox $1 \%$ ) samples stored at $4{ }^{\circ} \mathrm{C}$ revealed a gradual decrease in the TVC that was slower than that for Group A, with the TVC decreasing from 3.5 to $<100 \mathrm{cfu} / \mathrm{g}$ by the 18th day of storage, while the TVC in Group G (Citrox $2 \%$ ) decreased quickly and reached $<100 \mathrm{cfu} / \mathrm{g}$ after 17 days of storage. 


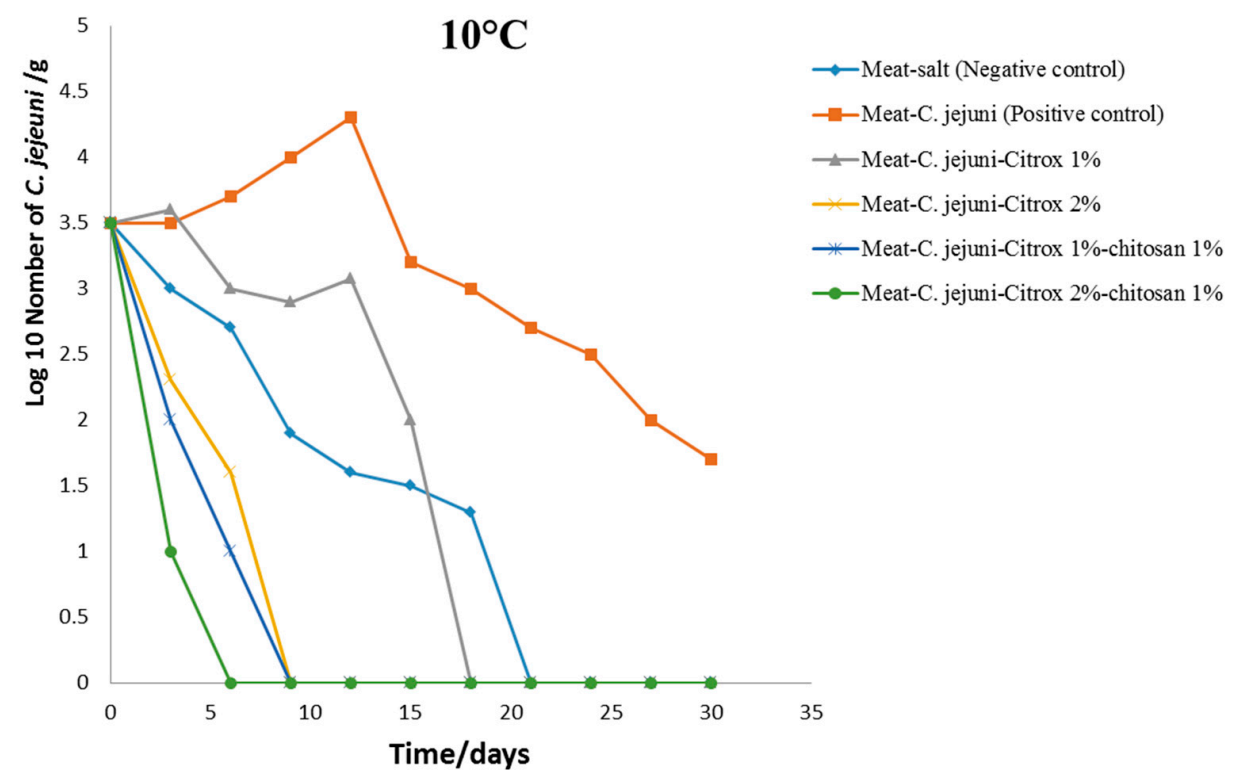

Figure 3. Total viable counts (TVCs) of Campylobacter jejuni in camel meat samples stored at $10^{\circ} \mathrm{C}$.

\section{$4^{\circ} \mathrm{C}$}

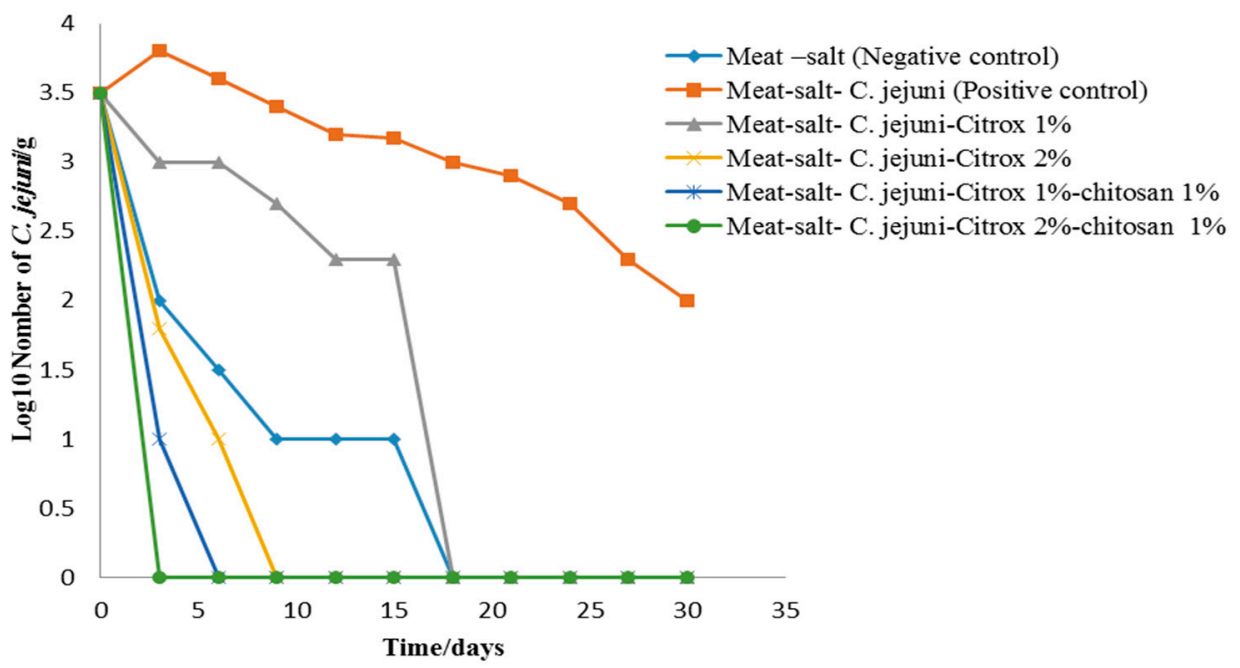

Figure 4. Total viable counts (TVCs) of C. jejuni in camel meat samples stored at $4{ }^{\circ} \mathrm{C}$.

The best treatment for camel meat stored at $4{ }^{\circ} \mathrm{C}$ consisted of $2 \%$ or $1 \%$ Citrox (Groups $\mathrm{E}$ and D) mixed with $1 \%$ chitosan. These treatments controlled the growth and TVC of C. jejuni, and the growth rate decreased quickly after three and six days. This finding indicates that the antimicrobial (anti-C. jejuni) activity of Citrox and chitosan together was higher than that of Citrox alone, with the $C$. jejuni growth curve entering the decline phase very quickly with the former treatment. Camel meat samples stored at $4{ }^{\circ} \mathrm{C}$ exhibited no contamination by $\mathrm{C}$. jejuni, unlike those stored at $10^{\circ} \mathrm{C}$. Storage temperature is considered one of the most important factors affecting microbial growth [27-29]. A storage temperature of $4{ }^{\circ} \mathrm{C}$ allows Campylobacter to remain viable in a food product during storage [30]. Many studies have mentioned that Campylobacter cells do not grow but do survive at $4{ }^{\circ} \mathrm{C}$. This inference is based on a lack of viability being observed when cells are cultured on agar medium, but signs of physiologic and metabolic activity, such as oxygen consumption, catalase activity, Adenosine triphosphate (ATP) generation, chemotaxis, aerotaxis, and protein synthesis, are observed [30]. However, the TVCs increased in our study and in a study conducted by Chan et al. (2001) [31]. A possible explanation comes from 
Hazeleger et al. (1998) [30], who observed variations in the phenotypes and genotypes of Campylobacter species and a variation in survival between different strains. Therefore, it is possible that at $4{ }^{\circ} \mathrm{C}$, only a few strains can grow, while the majority of strains can only survive.

Microbial communities change depending on the temperature [29,32]. According to European Food Safety Authority (EFSA) estimates, microbial communities can be considerably reduced if all slaughtered poultry batches comply with microbiological criteria, with a critical limit of 1000 or $500 \mathrm{cfu} / \mathrm{g}$ in neck and breast skin [33]. To reliably quantify the extent of $C$. jejuni contamination in such samples, appropriate (rapid, accurate, reliable, and reasonably priced) enumeration methods should be used. The storage of packaged camel meat samples under vacuum at 4 or $10^{\circ} \mathrm{C}$ is important because Campylobacter is microaerophilic, making such conditions necessary to reduce its growth and survival. Microaerophilic conditions help Campylobacter cope with oxidative stress and toxic products, which are produced during oxygen metabolism. Therefore, bacteria can survive in foods in numbers sufficient to cause infection, despite the constraints imposed by this sensitivity [34]. Aerotolerance has also been reported in numerous studies (Vercellone et al., 1990) [35], and it has even been suggested that Campylobacter spp. can adapt to aerobic metabolism [36].

\section{3. $p H$}

During the storage of camel meat samples at $10{ }^{\circ} \mathrm{C}$, reductions in the $\mathrm{pH}$ were noted for the six groups (Figure 5). The $\mathrm{pH}$ of the camel meat samples treated with $\mathrm{NaCl}$ (saline solution) was 6.0, and this value was reduced to approximately 4.0 after 30 days of storage. Camel meat samples treated with 1 and $2 \%$ Citrox combined with $1 \%$ chitosan had an initial $\mathrm{pH}$ of 5.0 to 5.5 , which reached $\sim 4.0$ after 30 days of storage. Highly perishable food, such as meat, which is stored under vacuum, shows a reduction in $\mathrm{pH}$ due to an increase in the content of microorganisms that cause spoilage. The relative decrease in the $\mathrm{pH}$ of the salt-treated camel meat samples compared with that of the $C$. jejuni-contaminated camel meat samples could be attributed to the ionization of $\mathrm{NaCl}$. Camel meat treated with 1 or $2 \%$ Citrox also exhibited a reduction in $\mathrm{pH}$, but this reduction was more than that observed for the samples treated with saline solution and $C$. jejuni due to the natural components of the Citrox solution, which include different acids.

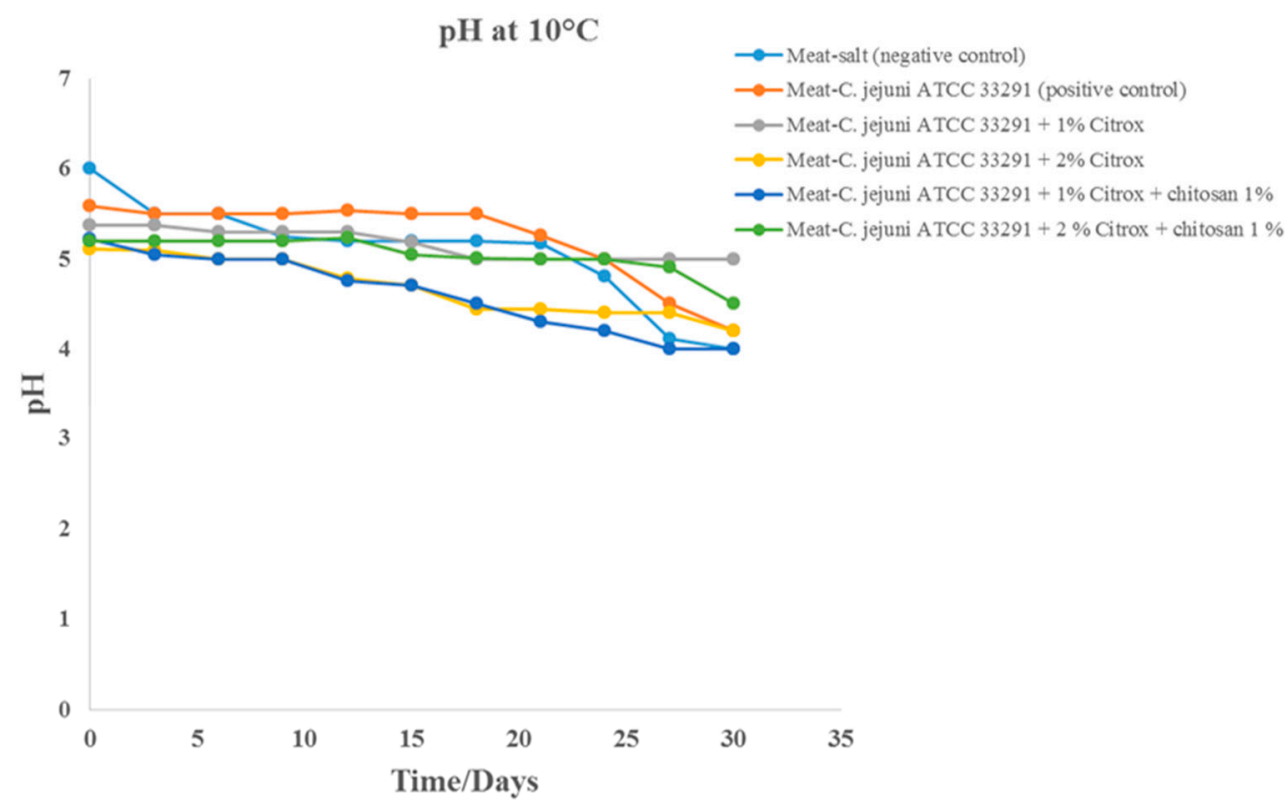

Figure 5. $\mathrm{pH}$ values of camel meat samples during storage at $10{ }^{\circ} \mathrm{C}$ for 30 days. 
Throughout the storage of the camel meat samples at $4{ }^{\circ} \mathrm{C}$, there was a reduction in $\mathrm{pH}$ in the six groups (Figure 6). The $\mathrm{pH}$ of the camel meat samples treated with $0.85 \%$ saline solution was 6.0, and this value was reduced to approximately 5.0 after 30 days of storage. The $\mathrm{pH}$ of the camel meat sample treated with C. jejuni and/or $0.85 \%$ salt was reduced to 5.0. However, the camel meat samples treated with Citrox at $1 \%$ or $2 \%$ and $1 \%$ chitosan with an initial $\mathrm{pH}$ ranging from 5.0 to 5.5 reached a $\mathrm{pH}$ of $\sim 3.0$ after 30 days of storage. The substantial decrease in the $\mathrm{pH}$ of the camel meat samples treated with $1 \%$ or $2 \%$ Citrox and $1 \%$ chitosan in comparison with that of the camel meat samples treated with C. jejuni or salt during storage at $4{ }^{\circ} \mathrm{C}$ could be attributed to the acid components of Citrox and a lack of active microorganisms, which could lead to changes in $\mathrm{pH}$. Campylobacter spp. are sensitive to strong acids, such as formic, acetic, ascorbic, and lactic acids, as shown in several studies [37].

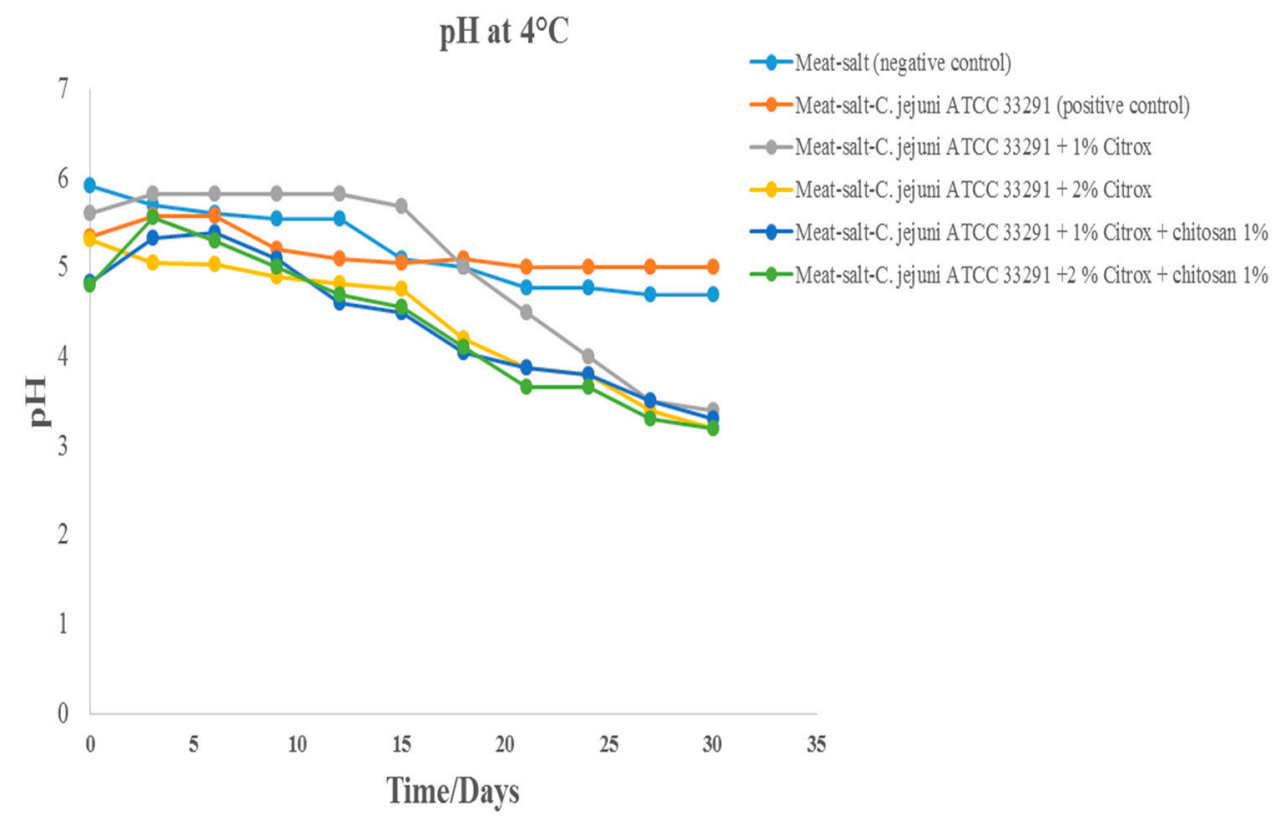

Figure 6. $\mathrm{pH}$ values of camel meat stored at $4{ }^{\circ} \mathrm{C}$ for 30 days.

The proteolytic activity of $C$. jejuni accelerates the reduction in $\mathrm{pH}$, but this reduction is limited by a low temperature $\left(4^{\circ} \mathrm{C}\right)$ during storage. Rio et al. (2007) [38] reported that dipping chicken meat in citric acid significantly decreased its $\mathrm{pH}$ after marination. The $\mathrm{pH}$ of meat products is influenced by many factors during storage, such as the duration of storage, the stability of the water-binding capacity and texture, and the redness [39]. C. jejuni grew well at an optimum $\mathrm{pH}$ range of 6.5 to 7.5 , while all strains grew well at a $\mathrm{pH}$ range of 5.5 to 8.0 [40]. At $\mathrm{pH} 5.0$, no $C$. jejuni survivors were detected after $24 \mathrm{~h}$, and at pH 9.0, the counts decreased rapidly, with no survivors detected after three days [41].

\subsection{Total Volatile Base Nitrogen (TVB-N)}

The shelf life of meat samples can be determined from the TVB-N released from microbial amino acid decarboxylase activity. In this study, after 30 days of storage at $10^{\circ} \mathrm{C}$, we found that the TVB-N values in camel meat treated with $C$. jejuni alone reached the highest value of $18.5 \mathrm{mg} / 100 \mathrm{~g}$ at $10{ }^{\circ} \mathrm{C}$ (Figure 7). This was significantly higher than the TVB-N values of camel meat samples treated with salt $(9.95 \mathrm{mg} / 100 \mathrm{~g}), 1 \%$ Citrox (10.99 mg/100 g), or $2 \%$ Citrox ( $8.9 \mathrm{mg} / 100 \mathrm{~g}$ ). However, the samples treated with $1 \%$ or $2 \%$ Citrox and $1 \%$ chitosan were stable, and their TVB-N values did not exceed $8.0 \mathrm{mg} / 100 \mathrm{~g}$.

After 30 days of storage at $4{ }^{\circ} \mathrm{C}$, the TVB-N values of camel meat treated with $\mathrm{C}$. jejuni alone reached their highest value of $14 \mathrm{mg} / 100 \mathrm{~g}$ (Figure 8). This was significantly higher than the TVB-N values of camel meat samples treated with salt $(9.88 \mathrm{mg} / 100 \mathrm{~g}), 1 \%$ Citrox $(11.55 \mathrm{mg} / 100 \mathrm{~g})$, or $2 \%$ Citrox (8.66 mg/100 g). However, samples treated with $1 \%$ or $2 \%$ 
Citrox and 1\% chitosan were stable, and their TVB-N values did not exceed $7.66 \mathrm{mg} / 100 \mathrm{~g}$. The storage of camel meat samples treated with Citrox and chitosan at $4{ }^{\circ} \mathrm{C}$ under vacuum was more effective against $\mathrm{C}$. jejuni than storage at $10^{\circ} \mathrm{C}$ : storage at $4{ }^{\circ} \mathrm{C}$ resulted in higher camel meat quality and improved safety.

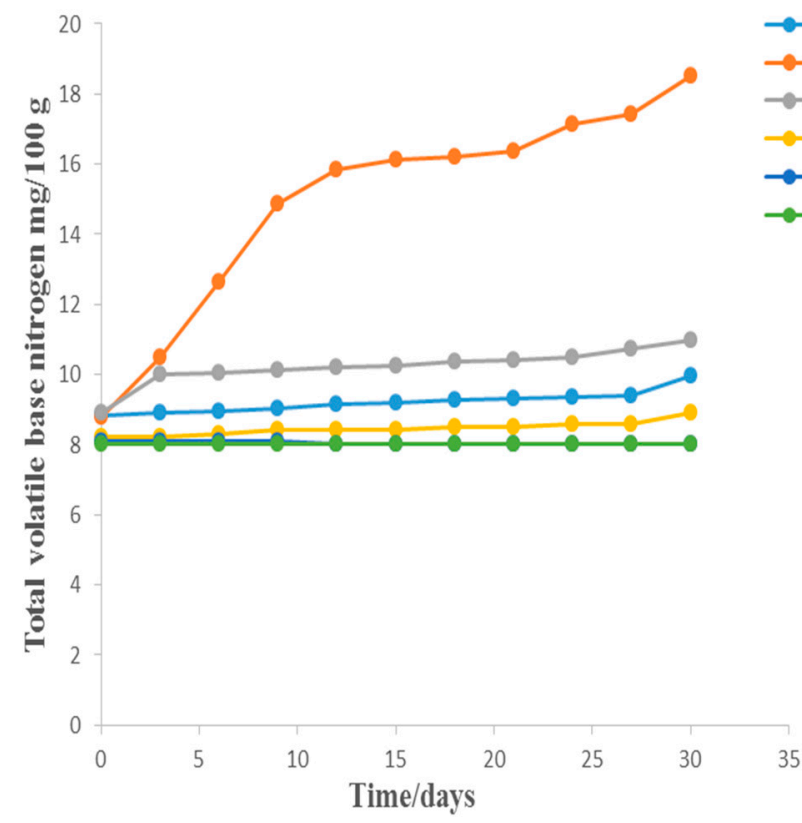

Figure 7. Total volatile base nitrogen (TVB-N) of camel meat samples during storage at $10^{\circ} \mathrm{C}$ for 30 days.

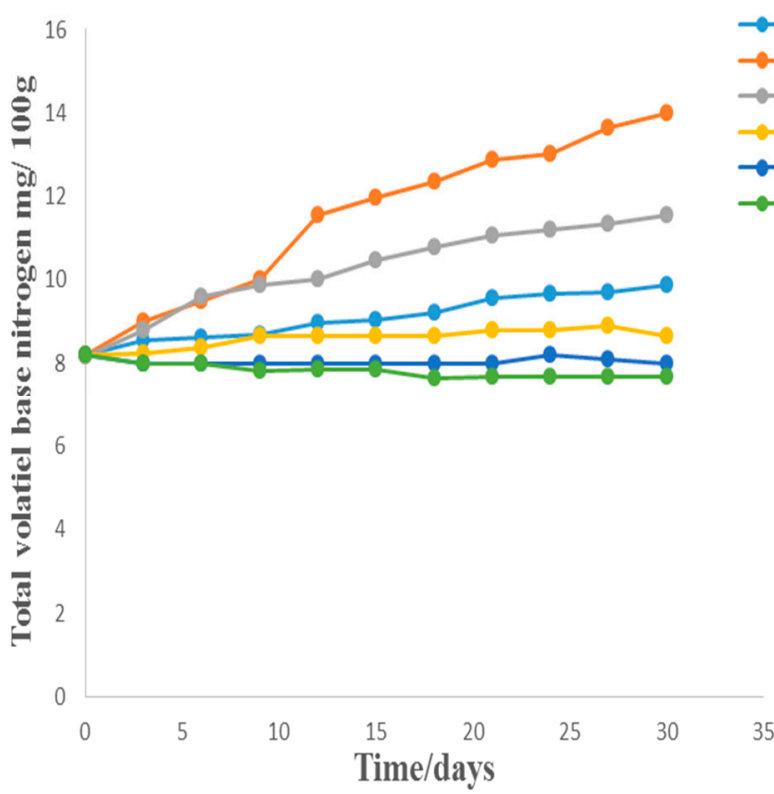

$\rightarrow-$ Meat-salt (negative control)

$\rightarrow-$ Meat-C. jejuni ATCC 33291 (positive control)

$\sim-$ Meat-C. jejuni ATCC $33291+1 \%$ Citrox

$\rightarrow-$ Meat-C. jejuni ATCC $33291+2 \%$ Citrox

$\rightarrow$ Meat-C. jejuni ATCC $33291+1 \%$ Citrox + chitosan $1 \%$

$\rightarrow-$ Meat-C. jejuni ATCC $33291+2 \%$ Citrox + chitosan $1 \%$

Figure 8. Total volatile base nitrogen (TVB-N) of camel meat samples during storage at $4{ }^{\circ} \mathrm{C}$ for 30 days.

TVB-N is an indicator of meat quality and safety. Measuring TVB-N can help determine spoilage in meat. Bell and Garout (1994) [42] explained that there is no consistent relationship between the TVB-N content of the surface and deep tissue of lean beef. They found that the TVB-N content of the surface was $0.2 \pm 0.5 \mathrm{mg}$ N/100 $\mathrm{g}$ higher than that of the deep tissue, indicating that microflora reached maximal levels $\left(10^{7} \mathrm{cells} / \mathrm{cm}^{2}\right)$ in 
the surface. Moreover, the TVB-N levels exceeded $18 \mathrm{mg}$ N/100 $\mathrm{g}$ in lean beef, with levels exceeding $24 \mathrm{mg} \mathrm{N} / 100 \mathrm{~g}$ when spoilage became organoleptically evident.

The preservation of meat and meat products using chemical methods to avoid microbial growth is not preferred by consumers. Generally, consumers worldwide dislike the addition of chemical additives to foods. Therefore, demand for the use of natural products as food additives and preservatives has increased. Citrox has plant origins, and in the presence of organic matter, its ingredients, including citric, ascorbic, and malic acids, have the ability to break down bacterial biofilms, extend shelf life, and control foodborne pathogens, such as methicillin-resistant S. aureus (Yehia, et al., 2019) [43] and Listeria monocytogenes (Tsiraki et al., 2017) [44], as determined by the European suspension test (BS EN 1276). TVB-N has been used in many studies to determine the quantity of biogenic amines produced through the microbiological contamination of foods [45-47].

A study on the effect of a 5 min treatment with $1 \%$ lactic acid on the counts of C. jejuni in broth showed that the TVCs were reduced by $2.1 \mathrm{log}$ units after exposure to low temperature [48], while dipping broiler chicken meat in $0.50 \%$ acetic acid or lactic acid for $10 \mathrm{~min}$ at $5{ }^{\circ} \mathrm{C}$ had little effect, with only a 0.07 - and 0.08 -log decrease in the counts of C. jejuni, respectively [48]. Thus, the effects of organic acids on Campylobacter may differ depending on whether testing is performed in broth or in a food matrix.

\subsection{Colour Values}

The six camel meat treatment groups in the present study are shown as color differentials in Table 1 . The $L^{*}$ values were significantly higher for the $C$ and $D$ groups (treated with $1 \%$ or $2 \%$ Citrox solution) than for the positive (B) and negative (A) controls on the 9th day of storage. The $\mathrm{L}^{*}$ values of the positive and negative controls were not significantly different. After nine days of storage, the $\mathrm{a}^{*}$ values were significantly higher in the samples treated with C. jejuni (group B, positive control) than in the samples in the other three groups.

A reduction in the red color of camel meat samples generally indicates the oxidation of lipids and pigments. Citric acid has been used to bind heme iron in myoglobin and prevent the formation of the pink color caused by acidification [49].

We found that the organic acid preservatives present in Citrox solution, such as citric, malic, and ascorbic acids, increased the lightness and redness and decreased the yellowness of the meat. These results are in agreement with those of Bilgili et al. [50], who reported that propionic acid had a small effect on the lightness and redness but significantly decreased the yellowness. The processing conditions during sample preparation include many intrinsic and extrinsic factors, such as $\mathrm{pH}$, temperature, storage time, and immersion chilling conditions, which also change the color of meat [51,52]. Additionally, the use of lactic acid at low concentrations affects the color of fresh and cooked meat [53]. Lactic acid at concentrations of $1.2 \%$ and $1.5 \%$ caused color deterioration in beef samples during display [53]. Additionally, Kotula and Thelappurate [54] showed that the addition of lactic acid to meat is important when determining the color of fresh and cooked meat.

The formation of metmyoglobin is considered as one of the factors affecting the color of specially packaged fresh beef. The reduction in metmyoglobin in fresh beef requires the removal or injection of oxygen at saturation levels in environmental packaging [55]. However, Djamel et al. [56] suggested that preservation of the red pigment in meat in its oxygenated form $(\mathrm{MbO} 2)$ requires the use of a high- $\mathrm{O}_{2}$ atmosphere. They also suggested that using $\mathrm{O}_{2}$ at high levels can promote lipid oxidation, leading to MetMb accumulation.

Using Citrox solution, which contains citric, malic, and ascorbic acids, decreases the redness and increases the lightness of meat [43]. Additionally, Bilgili et al. [50] reported that using propionic acid had little effect on lightness and redness but significantly decreased yellowness. 
Table 1. Hunter color values of camel meat samples treated with Citrox and chitosan and stored at 4 or $10{ }^{\circ} \mathrm{C}$ for 30 days.

\begin{tabular}{|c|c|c|c|c|c|c|c|c|c|c|c|c|c|c|c|c|c|c|c|c|c|c|c|c|}
\hline \multirow{2}{*}{$\begin{array}{l}\text { Hunter } \\
\text { Color }\end{array}$} & \multirow{2}{*}{$\begin{array}{ll} & \text { Treatments } \\
\text { Temperatures }\left({ }^{\circ} \mathrm{C}\right) & \end{array}$} & \multicolumn{2}{|c|}{0} & \multicolumn{2}{|c|}{3} & \multicolumn{2}{|c|}{6} & \multicolumn{2}{|c|}{9} & \multicolumn{2}{|c|}{12} & \multicolumn{2}{|c|}{15} & \multicolumn{2}{|c|}{18} & \multicolumn{2}{|c|}{21} & \multicolumn{2}{|c|}{24} & \multicolumn{2}{|c|}{27} & \multicolumn{2}{|c|}{30} & \multirow[b]{2}{*}{ Mean } \\
\hline & & 4 & 10 & 4 & 10 & 4 & 10 & 4 & 10 & 4 & 10 & 4 & 10 & 4 & 10 & 4 & 10 & 4 & 10 & 4 & 10 & 4 & 10 & \\
\hline \multirow{7}{*}{$\mathrm{L}^{*}$} & M-S (A) & 39.76 & 38.25 & 40.67 & 38.47 & 40.81 & 38.91 & 40.45 & 40.23 & 40.51 & 40.39 & 47.93 & 51.6 & 46.47 & 48.29 & 45.74 & 47.13 & 45 & 45.05 & 44.99 & 42.2 & 44 & 43 & $43.17^{\mathrm{e}}$ \\
\hline & M-S-C. jejuni (B) & 37.71 & 37.93 & 43.5 & 41.33 & 43.18 & 41.48 & 45.07 & 42.02 & 45.22 & 44.48 & 45.65 & 45.72 & 46.07 & 48.93 & 43.88 & 46.21 & 43.84 & 4487 & 41.2 & 42.84 & 41 & 42.02 & $43.37^{c}$ \\
\hline & M-S-C. jejuni-C 1\% (C) & 39.33 & 38.37 & 40.24 & 39.11 & 44.22 & 39.39 & 49.1 & 43.17 & 49.45 & 44.79 & 49.21 & 45.22 & 48.81 & 46.7 & 45.07 & 45.24 & 43.09 & 43.01 & 42.41 & 40.96 & 42.01 & 40.54 & $43.36^{\mathrm{d}}$ \\
\hline & M-S-C. jejuni-C 2\% (D) & 34.92 & 38.86 & 39.21 & 43.55 & 40.29 & 43.96 & 42.65 & 44.2 & 44.46 & 47.7 & 47.93 & 46.68 & 47.19 & 46.33 & 46.63 & 46.14 & 44.45 & 45.67 & 42.6 & 42.77 & 42 & 42.66 & $43.61^{b}$ \\
\hline & M-S-C. jejuni-C 1\%-C 1\% (E) & 41.87 & 39.64 & 42.15 & 42.8 & 44.78 & 48.41 & 45.43 & 50.98 & 47.17 & 50.92 & 48.93 & 53.58 & 48.2 & 49.63 & 46.63 & 49.94 & 44.83 & 48.2 & 42.5 & 46.38 & 42.52 & 45 & $46.38^{a}$ \\
\hline & M-S-C. jejuni-C $1 \%-C 2 \%(F)$ & 40.3 & 40.96 & 42.77 & 40.99 & 43.21 & 41.54 & 47.18 & 44.46 & 47.53 & 46.6 & 46.36 & 48.73 & 45.5 & 44.1 & 45.4 & 44 & 44.56 & 43.52 & 43.2 & 43 & 42.33 & 42.36 & $44.02^{\mathrm{f}}$ \\
\hline & M-S (A) & 6.7 & 10.35 & 8.69 & 12.23 & 7.7 & 9.9 & 7.27 & 9.42 & 10.97 & 9.38 & 12.1 & 8.82 & 9.47 & 7.48 & 9.05 & 6.92 & 6.65 & 6 & 6.5 & 5.46 & 6 & 5.44 & $8.29^{\mathrm{e}}$ \\
\hline \multirow{5}{*}{$a$} & M-S-C. jejuni (B) & 10.46 & 8.35 & 11.9 & 8.52 & 12.4 & 12.5 & 13.8 & 12.49 & 12.8 & 12.67 & 11.62 & 11.49 & 11.44 & 10.99 & 11.34 & 8.68 & 8.03 & 7.05 & 6.48 & 6.25 & 6.25 & 7.58 & $10.14^{b}$ \\
\hline & M-S-C. jejuni-C 1\% (C) & 6.07 & 9.65 & 9.06 & 9.34 & 9.78 & 9.5 & 11.7 & 10.84 & 12.57 & 12.83 & 14.21 & 9.92 & 11.45 & 8.78 & 8.06 & 6.81 & 7.3 & 7.81 & 5.16 & 6.58 & 6.5 & 6 & $9.08^{c}$ \\
\hline & M-S-C. jejuni-C 2\% (D) & 6.82 & 4.51 & 7.77 & 9.1 & 8.31 & 9.19 & 8.81 & 10.42 & 15.97 & 11.79 & 15.38 & 13.59 & 13.48 & 10.95 & 12.79 & 10.49 & 11.97 & 9.76 & 8.92 & 9.59 & 6 & 8 & $10.16^{\mathrm{a}}$ \\
\hline & M-S-C. jejuni-C 1\%-C $1 \%$ (E) & 6.95 & 9.57 & 8.35 & 9.89 & 8.24 & 10.65 & 9.18 & 11.06 & 11.71 & 8.85 & 11.15 & 8.25 & 9.79 & 7.99 & 9.09 & 7 & 8.25 & 7 & 6.05 & 6.2 & 6 & 4.47 & $8.44^{\mathrm{d}}$ \\
\hline & M-S-C. jejuni-C 2\%-Ch 1\% (F) & 6.25 & 3.53 & 6.19 & 5.45 & 6.61 & 6.41 & 12.32 & 7.94 & 12.94 & 7.43 & 8.21 & 8.57 & 7.12 & 8.97 & 7.1 & 7 & 5.08 & 6 & 6 & 6 & 5.99 & 4.56 & $7.07^{\mathrm{f}}$ \\
\hline \multirow{6}{*}{$b^{*}$} & Mean & 7.2 & 7.66 & 8.66 & 9.08 & 8.84 & 9.69 & 10.51 & 10.36 & 12.82 & 10.49 & 12.11 & 10.1 & 10.45 & 9.19 & 9.57 & 7.81 & 7.88 & 7.27 & 6.51 & 6.68 & 6.12 & 6 & - \\
\hline & M-S (A) & 4.27 & 6.29 & 4.58 & 6.23 & 5.88 & 7 & 7.42 & 7.5 & 7.65 & 7.99 & 8.79 & 8 & 9.98 & 8.95 & 10.24 & 9.86 & 9.89 & 7 & 8.02 & 6.66 & 6 & 5.99 & $7.46^{\mathrm{e}}$ \\
\hline & M-S-C. jejuni (B) & 7.21 & 6.22 & 7.83 & 6.65 & 8.32 & 7.37 & 8.5 & 8.05 & 9.8 & 7.58 & 11.55 & 9.69 & 8.02 & 8.99 & 6.4 & 6.58 & 5.39 & 6.43 & 5.94 & 4.59 & 5.5 & 5 & $7.34^{\mathrm{f}}$ \\
\hline & M-S-C. jejuni-C 1\%-C 1\% (E) & 6.6 & 6.99 & 7.74 & 9.41 & 8.03 & 9.88 & 9.02 & 10.19 & 9.92 & 0.241 & 12.23 & 10.96 & 10.6 & 11.26 & 9.71 & 9.21 & 9.23 & 8.83 & 6.23 & 8.63 & 6 & 5.66 & $8.48^{b}$ \\
\hline & M-S-C. jejuni-C 2\%-Ch 1\% (F) & 6 & 7.14 & 8.47 & 10.92 & 9.72 & 9.66 & 9.85 & 11.28 & 11.43 & 12.95 & 11.17 & 11.63 & 10.63 & 10.49 & 9.53 & 10 & 9 & 8.55 & 8.5 & 8 & 6 & 6 & $9.40^{\mathrm{a}}$ \\
\hline & Mean & 6.25 & 6.33 & 7.227 & 7.76 & 8.157 & 8.39 & 9.27 & 9 & 9.965 & 7.968 & 10.9 & 10.15 & 10.15 & 9.93 & 8.195 & 8.767 & 7.61 & 7.85 & 6.63 & 6.93 & 5.67 & 5.35 & - \\
\hline
\end{tabular}

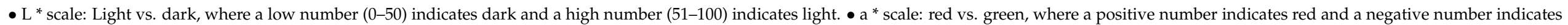

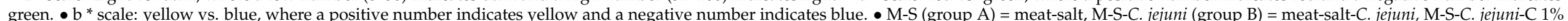

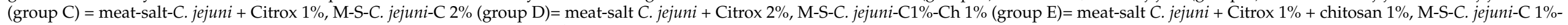
$\mathrm{Ch} 1 \%\left(\right.$ group F) = meat-salt-C. jejuni + Citrox $2 \%$ + chitosan $1 \%$. ${ }^{a}, \mathrm{~b}, \mathrm{c}, \mathrm{d}, \mathrm{e}, \mathrm{f}$ Different superscripted letters indicate significant differences $(P \leq 0.05)$ among the observed values within columns. 
The conditions used during slaughtering, such as the scalding temperature, storage time $[51,52,57], \mathrm{pH}$ (Heath and Wabeck, and immersion chilling conditions (Lyon and Cason, [53], affect the color of meat. Kim et al. [58] reported that the immersion of meat in citric acid solution prevented the increase in redness in meat products conferred by the sous-vide process. An increase in citric acid concentration had reduced the pink color by inducing the thermal denaturation of myoglobin during refrigerated storage.

\subsection{Sensory Evaluation}

A sensory evaluation of the camel meat quality indicated that the samples treated with C. jejuni (group B) had a lower sensory score than the samples in the negative control (A) and the other four groups (groups C, D, E, and F; Table 2). Sensory tests performed with Groups C and D (treated with $1 \%$ and $2 \%$ Citrox, respectively) revealed moderate sensory scores for color, odor, flavor, taste, and tenderness. The use of $1 \%$ or $2 \%$ Citrox mixed with $1 \%$ chitosan resulted in higher scores for color, odor, flavor, taste, tenderness, and overall acceptability than any other treatment.

Table 2. Sensory evaluation of camel meat samples treated with $1 \%$ or $2 \%$ Citrox.

\begin{tabular}{|c|c|c|c|c|c|c|}
\hline Treatments & Color & Odor & Flavor & Taste & Tenderness & $\begin{array}{c}\text { Overall } \\
\text { Acceptability }\end{array}$ \\
\hline Camel meat-salt (group A) & $5.0^{\mathrm{c}}$ & $4.0^{\mathrm{d}, \mathrm{e}}$ & $4.5^{c}$ & $5.0^{\mathrm{c}}$ & $4.5^{b}$ & $5.2^{\mathrm{c}}$ \\
\hline Camel meat-C. jejuni (group B) & $3.0^{\mathrm{d}}$ & $2.0^{\mathrm{f}}$ & $2.0^{\mathrm{d}}$ & $2.0^{\mathrm{e}}$ & $2.3^{d}$ & $2.5^{\mathrm{e}}$ \\
\hline Camel meat-C. jejuni- Citrox 1\% (group C) & $4.9^{\mathrm{a}, \mathrm{b}, \mathrm{c}}$ & $4.65^{\mathrm{d}}$ & $4.6^{\mathrm{c}}$ & $4.9^{\mathrm{d}}$ & $4.5^{\mathrm{b}}$ & $4.0^{\mathrm{d}}$ \\
\hline Camel meat-C. jejuni-Citrox $2 \%$ (group D) & $5.0^{\mathrm{c}}$ & $5.0^{c}$ & $4.9^{\mathrm{a}, \mathrm{b}}$ & $5.0^{\mathrm{c}}$ & $4.4^{\mathrm{b}}$ & $4.0^{\mathrm{d}}$ \\
\hline Camel meat-C. jejuni-Citrox 1\%-Chitosan 1\% (group E) & $5.5^{\mathrm{a}, \mathrm{b}}$ & $6.0^{\mathrm{a}, \mathrm{b}}$ & $5.0^{\mathrm{b}}$ & $5.5^{b}$ & $4.5^{\mathrm{b}}$ & $6.0^{\mathrm{b}}$ \\
\hline Camel meat-C. jejuni-Citrox $2 \%$ - Chitosan $1 \%$ (group F) & $6.0^{\mathrm{a}}$ & $6.2^{\mathrm{a}}$ & $5.5^{\mathrm{a}}$ & $6.0^{\mathrm{a}}$ & $4.6^{\mathrm{a}}$ & $6.4^{\mathrm{a}}$ \\
\hline Mean & $4.9^{\mathrm{a}}$ & $4.6^{\mathrm{c}, \mathrm{d}}$ & $4.41^{\mathrm{e}}$ & $4.73^{\mathrm{b}}$ & $4.0^{\mathrm{f}}$ & $4.68^{c}$ \\
\hline
\end{tabular}

A nine-point hedonic scale ( $9=$ like extremely, $4-5=$ like moderately, $1=$ dislike extremely) was used for all sensory parameters. $\mathrm{a}, \mathrm{b}, \mathrm{c}, \mathrm{d}, \mathrm{e}, \mathrm{f}$ Different superscripted letters indicate significant differences $(P \leq 0.05)$ among the observed values within columns.

The addition of citrus extract $(0.1 \mathrm{~mL} / 100 \mathrm{~g})$ alone and in combination with an oxygen absorber reduced the TVCs in aerobically packaged ground chicken meat by 0.5 and $1.5 \log \mathrm{cfu} / \mathrm{g}$, respectively [59]. Vardaka et al. [60] combined citric extract and chitosan to treat turkey meat to improve its taste and odor, and their results were in agreement with the findings of Petrou et al. [61], who reported that chitosan, applied either alone or in combination with oregano, did not negatively influence the taste of chicken breast meat. Both chitosan and Citrox were sensorially acceptable when added to turkey samples, with chitosan characterized as having spicy, fruity, and oriental flavors and Citrox characterized as having a citrus-like flavor. Moreover, the addition of both citrus extract and chitosan may provide new flavors and options for poultry products. However, further sensory tests are needed to examine this possibility [60].

In another study, a turkey sample sensory profile was acceptable after treatment with chitosan and Citrox. The addition of chitosan improved the flavor, with unique spicy and fruity odors, while Citrox was characterized by citric-like flavors. Moreover, a combination of Citrox and chitosan imparted a new flavor and taste to poultry, but more sensory analysis is still needed to evaluate all of these possibilities [60].

The beneficial effect of chitosan on the quality and sensory profile of meat was attributed to its antibacterial activity and ability to prevent lipid oxidation and preserve color and nutrients, all of which persist in fresh products [62].

Lawrie [63] mentioned that the change in fresh or frozen beef flavor during storage was caused by the slow loss of highly volatile substances. However, changes in odor or taste during beef storage were due to the growth of microorganisms and the breakdown of their chemical components. Some microorganisms secrete the enzyme lipase and split lipids into fatty acids, with more or less unpleasant consequences according to their nature. The off-odor of beef depends on the nature of the beef (fresh, cured, or comminuted) and 
the conditions, such as the storage temperature, that the microorganism is growing in. It is generally accepted that the autoxidation of membrane phospholipids is largely responsible for the development of an off-odor [64]. However, Calkins and Hodgen [65] stated that high polyunsaturated fatty acid contents in diets may contribute to the appearance of off-flavors in fresh beef muscles.

The addition of Citrox and chitosan to turkey meat led to an antibacterial effect against the growth of E. coli and S. enterica, which was attributed to the disintegration of the protective outer membrane by Citrox, which could increase the sensitivity of the cell to chitosan. The nature of the chitosan polymer and its emulsification stabilized and enhanced the efficiency of citrus essential oils when used synergistically [60].

\section{Conclusions}

The shelf life of fresh camel meat is highly dependent on many intrinsic and extrinsic factors, such as the storage temperature, the $\mathrm{pH}$, water activity, microbial contamination by pathogens, lipid oxidation, and color changes, and if these factors are controlled, the shelf life can be extended. One of the ways to extend the shelf life of fresh beef is by using organic acids, such as Citrox, alone or in combination with chitosan. Citrox mixed with chitosan controlled the growth of $C$. jejuni at 4 and $10{ }^{\circ} \mathrm{C}$, and the results of this study indicate that Citrox plus chitosan could be used as an antimicrobial treatment against Campylobacter jejuni growth in vacuum-packed camel meat stored under refrigerated conditions at $4{ }^{\circ} \mathrm{C}$ or at a mild temperature of $10^{\circ} \mathrm{C}$, where populations of this pathogen were maintained at low levels.

Author Contributions: H.M.Y. and A.H.A.-M. conceived the study idea; N.A.A. and S.M.K. performed the statistical analysis; H.M.Y. and H.M.S.N. wrote the manuscript with support from M.F.E., M.M.A.-D. and A.A.A. provided critical feedback and helped shape the research. All authors have read and agreed to the published version of the manuscript.

Funding: This research was funded by the Deanship of Scientific Research at Princess Nourah bint Abdulrahman University through the Fast-Track research funding program.

Institutional Review Board Statement: Not applicable.

Informed Consent Statement: Not applicable.

Data Availability Statement: The raw data of the results presented in this study are available on request from the corresponding author.

Acknowledgments: This research was funded by the Deanship of Scientific Research at Princess Nourah bint Abdulrahman University through the Fast-Track research funding program.

Conflicts of Interest: The authors declare no conflict of interest. The funders had no role in the design of the study; in the collection, analyses, or interpretation of data; in the writing of the manuscript, or in the decision to publish the results.

\section{References}

1. Harvala, H.; Rosendal, T.; Lahti, E.; Engvall, E.O.; Brytting, M.; Wallensten, A.; Lindberg, A. Epidemiology of Campylobacter jejuni infections in Sweden, November 2011-October 2012: Is the severity of infection associated with C. jejuni sequence type? Infect. Ecol. Epidemiol. 2016, 6, 1-10. [CrossRef]

2. Iglesias-Torrens, Y.; Miró, E.; Guirado, P.; Llovet, T.; Muñoz, C.; Cerdà-Cuéllar, M.; Madrid, C.; Balsalobre, C.; Navarro, F. Population structure, antimicrobial resistance, and virulence-associated genes in Campylobacter jejuni isolated from three ecological niches: Gastroenteritis patients, broilers, and wild birds. Front. Microbiol. 2018, 9, 1-13. [CrossRef]

3. Nisar, M.; Mushtaq, M.H.; Shehzad, W.; Hussain, A.; Nasar, M.; Nagaraja, K.V.; Goyal, S.M. Occurrence of Campylobacter in retail meat in Lahore, Pakistan. Acta Trop. 2018, 185, 42-45. [CrossRef]

4. Hsieh, Y.H.; Sulaiman, I.M. Campylobacteriosis: An emerging infectious foodborne disease. In Foodborne Diseases; Holban, A.M., Grumezescu, A.M., Eds.; Academic Press: Cambridge, MA, USA, 2018; pp. 119-155.

5. Sharma, K.P.; Chattopadhyay, U.K.; Naskar, K. Prevalence of Campylobacter species in raw meat samples sold in open markets of Kolkata city. Int. J. Environ. Agric. Biotech. 2016, 9, 535-539. [CrossRef] 
6. Carron, M.; Chang, Y.M.; Momanyi, K.; Akoko, J.; Kiiru, J.; Bettridge, J.; Chaloner, G.; Rushton, J.; O’Brien, S.; Williams, N.; et al. Campylobacter, a zoonotic pathogen of global importance: Prevalence and risk factors in the fast-evolving chicken meat system of Nairobi, Kenya. PLoS Negl. Trop. Dis. 2018, 12, 1-18.

7. Zanetti, F.; Varoli, O.; Stampi, S.; de Luca, G. Prevalence of thermophilic Campylobacter and Arcobacter butzleri in food of animal origin. Int. J. Food Microbiol. 1996, 33, 315-321. [CrossRef]

8. Jorgensen, F.; Bailey, R.; Williams, S.; Henderson, P.; Wareing, D.R.; Bolton, F.J.; Frost, J.A.; Ward, L.; Humphrey, T.J. Prevalence and numbers of Salmonella and Campylobacter spp. on raw, whole chickens in relation to sampling methods. Int. J. Food Microbiol. 2002, 76, 151-164. [CrossRef]

9. Whyte, P.; McGill, K.; Cowley, D.; Madden, R.H.; Moran, L.; Scates, P.; Carroll, C.; O’Leary, A.; Fanning, S.; Collins, J.D.; et al. Occurrence ofCampylobacter in retail foods in Ireland. Int. J. Food Microbiol. 2004, 95, 111-118. [CrossRef] [PubMed]

10. Ndahi, M.D.; Kwaga, J.K.P.; Bello, M.; Kabir, J.; Umoh, V.J.; Yakubu, S.E.; Nok, A.J. Prevalence and antimicrobial susceptibili ty of Listeria monocytogenes and methicillin-resistant Staphylococcus aureus strains from raw meat and meat products in Zaria, Nigeria. Lett. Appl. Microbiol. 2013, 58, 262-269. [CrossRef]

11. Camino, F.M.M.; Arisseto-Bragotto, A.P.; Block, J.M. Food quality, food-borne diseases, and food safety in the Brazilian food industry. FQS 2017, 1, 13-27.

12. Epps, S.; Harvey, R.; Hume, M.; Phillips, T.; Anderson, R.; Nisbet, D. Foodborne Campylobacter: Infections, metabolism, pathogenesis and reservoirs. Int. J. Environ. Res. Public Health. 2013, 10, 6292-6304. [CrossRef] [PubMed]

13. El-Badawi, A.Y. The present situation of animal protein in Egypt and the role of camels in providing cheap and healthy meat for people in poor greenery lands. Int. J. Avian Wildl. Biol. 2018, 3, 319-322.

14. Schirone, M.; Visciano, P.; Tofalo, R.; Suzzi, G. Editorial: Biological Hazards in Food. Front. Microbiol. 2017. [CrossRef]

15. Naas, H.T.; Almajdoubi, Z.; Garbaj, A.M.; Azwai, S.M.; Gammoudi, F.T.; Abolghait, S.K.; Eldaghayes, I.M. Molecular identification and antibiogram of Enterococcus spp. isolated on Enterococcus selective differential (ESD) media from meat, meat products and seafood in Libya. J. Microbiol. Biotechnol. Food Sci. 2020, 10, 1264-1268. [CrossRef]

16. Seda Tiğli, R.; Karakeçili, A.; Gümüşderelioğlu, M. In vitro characterization of chitosan scaffolds: Influence of composition and deacetylation degree. J. Mater. Sci. Mater. Med. 2007, 18, 1665-1674. [CrossRef]

17. Biagini, B.; Muzzarelli, R.A.; Giardino, R.; Castaldini, C. Biological materials for wound healing. In Advances in Chitin and Chitosan; Brine, C.J., Sandford, P.A., Zikakis, J.P., Eds.; Elsevier: London, UK, 1992; pp. 16-24.

18. Zhang, J.; Xia, W.; Liu, P.; Cheng, Q.; Tahirou, T.; Gu, W.; Li, B. Chitosan modification and pharmaceutical/biomedical applications. Mar. Drugs 2010, 8, 1962-1987. [CrossRef]

19. Rinaudo, M. Chitin and chitosan: Properties and applications. Prog. Polym. Sci. 2006, 31, 603-632. [CrossRef]

20. Sankararamakrishnan, N.; Sanghi, R. Preparation and characterization of a novel xanthated chitosan. Carbohydr. Polym. 2006, 66, 160-167. [CrossRef]

21. Kurita, K. Chitin and chitosan: Functional biopolymers from marine crustaceans. Mar. Biotechnol. 2006, 8, 203-226. [CrossRef] [PubMed]

22. Mourya, V.K.; Inamdar, N.N.; Tiwari, A. Carboxymethyl chitosan and its applications. Adv. Mater. Lett. 2010, 1, 11-33. [CrossRef]

23. Kong, M.; Chen, X.G.; Xing, K.; Park, H.J. Antimicrobial properties of chitosan and mode of action: A state of the art review. Int. J. Food Microbiol. 2010, 144, 51-63. [CrossRef] [PubMed]

24. Roller, S.; Sagoo, S.; Board, R.; O’Mahony, T.; Caplice, E.; Fitzgerald, G.; Fogden, M.; Owen, M.; Fletcher, H. Novel combinations of chitosan, carnocin and sulphite for the preservation of chilled pork sausages. Meat Sci. 2002, 62, 165-177. [CrossRef]

25. AOAC. Official Methods of Analysis, 3rd ed.; Association of Official Analytical Chemist: Washington, DC, USA, 1990.

26. SAS Institute Inc. SAS/STAT User's Guide; Release 6.03; SAS Inst.: Cary, NC, USA, 1998.

27. Nedwell, D.B. Effect of low temperature on microbial growth: lowered affinity for substrates limits growth at low temperature. FEMS Microbiol. Ecol. 1999, 30, 101-111. [CrossRef]

28. Smolander, M.; Alakomi, H.L.; Ritvanen, T.; Vainionpää, J.; Ahvenainen, R. Monitoring of the quality of modified atmospherepackaged broiler chicken cuts stored in different temperatures conditions. A time-temperature indicators as quality indicating tools. Food Control 2004, 15, 217-229. [CrossRef]

29. Karadag, D.; Puhakka, J.A. Effect of changing temperature on anaerobic hydrogen production and microbial community composition in an open-mixed culture bioreactor. Int. J. Hydrog. Energy 2010, 35, 10954-10959. [CrossRef]

30. Hazeleger, W.C.; Wouters, J.A.; Rombouts, F.M.; Abee, T. Physiological activity of Campylobacter jejuni far below the minimal growth temperature. Appl. Environ. Microbiol. 1998, 64, 3917-3922. [CrossRef]

31. Chan, K.F.; Le Tran, H.; Kanenaka, R.Y.; Kathariou, S. Survival of clinical and poultry-derived isolates of Campylobacter jejuni at a low temperature $\left(4^{\circ} \mathrm{C}\right)$. Appl. Environ. Microbiol. 2001, 67, 4186-4191. [CrossRef]

32. Franciosi, E.; Settanni, L.; Cologna, N.; Cavazza, A.; Poznanski, E. Microbial analysis of raw cows' milk used for cheese making: Influence of storage treatments on microbial composition and other technological traits. World J. Microbiol. Biotechnol. 2011, 27, 171-180. [CrossRef]

33. Debretsion, A.; Habtemariam, T.; Wilson, S.; Nganwa, D.; Yehualaeshet, T. Real-time PCR assay for rapid detection and quantification of Campylobacter jejuni on chicken rinses from poultry processing plant. Mol. Cell. Probes. 2007, 21, 177-181. [CrossRef]

34. Humphrey, T.J. Campylobacter jejuni: some aspects of epidemiology, detection and control. Br. Food J. 1992, 94, 21-25. [CrossRef] 
35. Vercellone, P.A.; Smibert, R.M.; Kreig, N.R. Catalase activity in Campylobacter jejuni: comparison of a wild-Type strain with an aerotolerant variant. Can. J. Microbiol. 1990, 36, 449-451. [CrossRef]

36. Jones, D.M.; Sutcliffe, E.M.; Rios, R.; Fox, A.J.; Curry, A. Campylobacter jejuni adapts to aerobic metabolism in the environment. J. Med. Microbiol. 1993, 38, 145-150. [CrossRef] [PubMed]

37. Chaveerach, P.; Ter Huurne, A.A.H.M.; Lipman, L.J.A.; Van Knapen, F. Survival and Resuscitation of Ten Strains of Campylobacter jejuni and Campylobacter coli under Acid Conditions. Appl. Environ. Microbiol. 2003, 69, 711-714. [CrossRef] [PubMed]

38. Rio, D.E.; Muriente, R.; Prieto, M.; Alonso-calleja, C.; Capite, R. Effectiveness of trisodium phosphate, acidified sodium chlorite, citric acid and peroxy acids against pathogenic bacteria on poultry during refrigerated storage. J. Food Prot. 2007, 70, 2063-2071. [PubMed]

39. Sammel, L.M.; Claus, J.R. Citric acid and sodium citrate effects on reducing pink color defect of cooked intact turkey breast and ground turkey rolls. J. Food Sci. 2003, 68, 874-878. [CrossRef]

40. Doyle, M.P.; Roman, D.J. Growth and survival of Campylobacter fetus subsp. jejuni as a function of temperature and pH. J. Food Prot. 1981, 44, 596-601. [CrossRef]

41. Christopher, F.M.; Smith, G.C.; Vanderzant, C. Effect of temperature and pH on the survival of Campylobacter fetus. J. Food Prot. 1982, 45, 253-259. [CrossRef]

42. Bell, R.G.; Garout, A.M. The effective product life of vaccum-packaged beef imported into Saudi Arabia by sea, as assessed by chemical, microbiological and organoleptic criteria. Meat Sci. 1994, 36, 381-396. [CrossRef]

43. Yehia, H.M.; Elkhadragy, M.F.; Al-Megrin, W.A.; Al-Masoud, A.H. Citrox improves the quality and shelf life of chicken fillets packed under vacuum and protects against some foodborne pathogens. Animals 2019, 9, 1062. [CrossRef]

44. Tsiraki, M.I.; Yehia, H.M.; Elobeid, T.; Osaili, T.; Sakkas, H.; Savvaidis, I.N. Viability of and Escherichia coli O157:H7 and Listeria monocytogenes in a delicatessen appetizer (yogurt-based) salad as affected by citrus extract (Citrox@) and storage temperature. Food Microbiol. 2018, 69, 11-17. [CrossRef]

45. Min, J.S.; Lee, S.O.; Jang, A.; Lee, M.; Kim, Y. Production of biogenic amines by microflora inoculated in meats. Asian Australas J. Anim. Sci. 2004, 17, 1472-1478. [CrossRef]

46. Min, J.S.; Lee, S.O.; Jang, A.; Jo, C.; Park, C.S.; Lee, M. Relationship between the concentration of biogenic amines and volatile basic nitrogen in fresh beef, pork, and chicken meat. Asian Australas J. Anim. Sci. 2007, 20, 1278-1284. [CrossRef]

47. Vinci, G.; Antonelli, M. Iogenic amines: Quality index of freshness in red and white meat. Food Control 2002, 13, 519-524. [CrossRef]

48. Stern, N.; Rothenberg, P.J.; Stone, J.M. Enumeration and reduction of Campylobacter jejuni in poultry and red meats. J. Food Prot. 1985, 73, 258-265. [CrossRef] [PubMed]

49. Kieffer, K.J.; Claus, J.R.; Wang, H. Inhibition of pink color development in cooked uncured ground turkey by the addition of citric acid. J. Muscle Foods 2000, 11, 235-243. [CrossRef]

50. Bilgil, S.F.; Conner, D.E.; Pinion, J.L.; Tamblyn, K.C. Broiler Skin Color as Affected by Organic Acids: Influence of Concentration and Method of Application. Poult. Sci. 1998, 77, 751-757. [CrossRef]

51. Heath, J.L.; Thomas, O.P. The xanthophyll content and color of broiler skin after scalding. Poult. Sci. 1973, 52, 967-971. [CrossRef]

52. Heath, J.L.; Thomas, O.P. The effect of scalding conditions on the xanthophyll content and color of broiler skin. Poult. Sci. 1974, 53, 1880-1885. [CrossRef]

53. Lyon, C.E.; Cason, J.A. Effect of water chilling on objective color of bruised and unbruised broiler tissue. Poult. Sci. 1995, 74, 1894-1899. [CrossRef]

54. Kotula, K.L.; Thelappurate, R. Microbiological and sensory attributes of retail cuts of beef treated with acetic and lactic acid solutions. J. Food Prot. 1994, 57, 665-670. [CrossRef]

55. Faustman, C.; Cassens, R.G. The biochemical basis for discoloration in fresh meat: A review. J. Muscle Foods 1990, 1, 217-243. [CrossRef]

56. Djamel, D.; Luis, M.; Armida, S.; José, A.; Pedro, R. Antioxidant effect of carnosine and carnitine in fresh beef steaks stored under modified atmosphere. J. Food Chem. 2003, 85, 453-459.

57. McKee, S.R.; Townsend, J.C.; Bilgili, S.F. Use of a scald additive to reduce levels of Salmonella typhimurium during poultry processing. Poult. Sci. 2008, 87, 1672-1677. [CrossRef] [PubMed]

58. Kim, J.H.; Hong, G.E.; Lim, K.W.; Park, W.; Lee, C.H. Influence of citric acid on the pink color and characteristics of sous vide processed chicken breasts during chill storage. Korean J. Food Sci. Anim. Resour. 2015, 35, 585-596. [CrossRef]

59. Mexis, S.F.; Chouliara, E.; Kontominas, M.G. Shelf life extension of ground chicken meat using an oxygen absorber and a citrus extract. LWT-Food Sci. Technol. 2012, 49, 21-27. [CrossRef]

60. Vardaka, V.D.; Yehia, H.M.; Savvaidis, I.N. Effects of Citrox and chitosan on the survival of Escherichia coli O157:H7 and Salmonella enterica in vacuum-packaged turkey meat. Food Microbiol. 2016, 58, 128-134. [CrossRef] [PubMed]

61. Petrou, S.; Tsiraki, M.; Giatrakou, V.; Savvaidis, I.N. Chitosan dipping or oregano oil treatments, singly or combined on modified atmosphere packaged chicken breast meat. Int. J. Food Microbiol. 2012, 156, 264-271. [CrossRef] [PubMed]

62. Hu, Z.; Ganzle, M.G. Challenges and opportunities related to the use of chitosan as a food preservative. J. Appl. Microbiol. 2018, 126, 1318-1331. [CrossRef] [PubMed]

63. Lawrie, R.A. Undesirable odor and taste. In Meat Science; Lawrie, R., Ed.; Woodhead Publishing: Cambridge, UK, 1991; pp. 219-230. 
64. Angelo, A.S.; Vercellotti, J.R.; Legendre, M.G.; VinnelT, C.H.; Kuan, J.W.; James, C., Jr.; Dupuy, H.P. Chemical and instrumental analyses of wormed-over flavor in beef. J. Food Sci. 1987, 52, 1163-1168. [CrossRef]

65. Calkins, C.R.; Hodgen, J.M. A fresh look at meat flavor. Meat Sci. 2007, 77, 63-80. [CrossRef] 